\title{
BASIS USAHA DENGAN E-COMMERCE BAGI MASYARAKAT DI KELURAHAN MARIANA ILIR BANYUASIN
}

\author{
Wawan Nurmansyah', Meylinda Mulyati², Achmad Alfian ${ }^{3}$, Hendrik Fery Herdiyatmoko ${ }^{4}$, \\ J.M.Sri Narhadi ${ }^{5}$ \\ ${ }^{12345}$ Universitas Katolik Musi Charitas Palembang
}

w_nurmansyah@ukmc.ac.id, meylinda@ukmc.ac.id, a_alfian@ukmc.ac.id, hendrik@ukmc.ac.id, narhadi@ukmc.ac.id

\begin{abstract}
Abstrak
Masyarakat saat ini dapat dengan mudah mengakses infrastruktur dari perkembangan teknologi seperti jaringan komunikasi, aplikasi online, transaksi perbankan online, pembayaran dengan e-money dan lain sebagainya. Aktifitas masyarakat dalam usaha yang masih secara konvensional, seperti jual beli produk yang dihasilkan dari pengerajinan rumah tangga atau yang sering disebut home industri tentunya masih memperlambat proses penjualan dan pangsapasar yang masih sempit.

Pengenalan teknologi informasi yang berbasis elektronik seperti surat elektronik ( $e$-mail) sudah sangat sering saat ini digunakan oleh masyarakat umum dalam memberikan dokumen atau pesan. Toko elektronik atau e-commerce membuat toko atau produk yang dibuat dapat disebarluaskan informasinya secara global dan tentunya membuat masyarakat umum manapun dapat memiliki toko online dan dapat menjual produknya sendiri atau produk orang lain dari aplikasi-aplikasi $e$-commerce yang sudah ada saat ini.

Toko elektronik yang dihasilkan dapat dikelola secara individu baik untuk menambahkan produk baru lainnya atau sistem pengiriman barang yang di lakukan apakah free ongkir atau berbayar.
\end{abstract}

Kata Kunci: Masyarakat, Teknologi, Elektronik, Toko, E-Commerce

\section{PENDAHULUAN}

Masyarakat saat ini dapat dengan mudah mengakses infrastruktur dari perkembangan teknologi seperti jaringan komunikasi, aplikasi online, transaksi perbankan online, pembayaran dengan e-money dan lain sebagainya. Kebutuhan masyarakat dalam melaksanakan kegiatan baik kegiatan formal dalam pekerjaannya sehari - hari atau pun melakukan kegiatan hiburan, bisa dikatakan tidak lepas dari teknologi, seperti contohnya media komunikasi yang saat ini sangat dibutuhkan masyarakat untuk terhubung dengan individu satu dengan lainnya.

Aktifitas masyarakat dalam usaha yang masih secara konvensional, seperti jual beli produk yang dihasilkan dari pengerajinan rumah tangga atau yang sering disebut home industri tentunya masih memperlambat proses penjualan dan pangsapasar yang masih sempit. Bagian bisnis rumahan ini sangat butuh sekali sentuhan teknologi dikarenakan teknologi dapat dikatakan memiliki efisiensi dan fleksibilitas yang baik karena dengan adanya teknologi basis mobile tentunya inilah hal yang sangat membantu para pengusaha rumahan untuk melaksanakan aktifitas bisnisnya.

Pengenalan teknologi informasi yang berbasis elektronik seperti surat elektronik (e-mail) sudah sangat sering saat ini digunakan oleh masyarakat umum dalam memberikan dokumen atau pesan. Teknologi informasi basis web, tentunya dapat memberikan tampilan informasi 24 jam bisa

Teknologi Informasi dan Komunikasi 
diakses siapapun dan dimanapun. Toko elektronik atau e-commerce dapat membuat toko atau produk yang dibuat bisa disebarluaskan informasinya secara global, tentunya ini membuat masyarakat umum dapat memiliki toko online dan dapat menjual produknya sendiri atau produk orang lain dari aplikasi-aplikasi e-commerce yang sudah ada saat ini. Penyedia aplikasi toko online saat ini yang dapat diakses adalah : tokopedia, shopee, lazada, OLX, buka lapak, zilinggo, e-bay. Aplikasi yang memberikan layanan toko online ini ada yang dimiliki oleh indonesia sendiri atau pihak luar dari indonesia, pada prinsipnya aplikasi toko online ini sama saja, yang membedakannya adalah dari sisi jarak. Sedangkan bahasa bisa kita setting tampilan bahasa ke bahasa indonesia.

Toko elektronik yang dihasilkan dapat dimanajemen secara individu baik untuk menambahkan produk baru lainnya atau sistem pengiriman barang yang di lakukan apakah free ongkir atau berbayar. Bagian fitur yang akan dihasilkan ini akan jauh lebih baik pengguna (masyarakan) menggunakan aplikasi basis server yang ada diindonesia saja karena lebih mudah untuk koordinasi dan komunikasi dengan pihak operator penyelenggara toko online tersebut.

Melalui kegiatan pengabdian pada masyarakat ini diharapkan dapat memberikan keterampilan dan pengetahuan kepada masyarakat khususnya ibu rumah tangga pada kelompok ibu rumah tangga di daerah Mariana Ilir, Banyuasin dan pemuda/pemudi karangtaruna, tentang pembuatan toko online. Pelatihan ini, bagi para ibu - ibu dalam kelompok ini bisa membuat toko online guna memasarkan produk produk buatan rumah mereka. Perempuan (ibu rumah tangga) juga mempunyai andil besar dalam kegiatan penanggulangan kemiskinan melalui pemberdayaan masyarakat dan kelompok. Salah satu buktinya, bahwa perempuan dapat meningkatkan kesejahteraan keluarganya dengan melakukan kegiatan usaha produktif rumah tangga (VH dan Susilowati, 2016). Selain itu juga kelompok ibu rumah tangga ini merupakan kelompok produktif yang dapat memanfaatkan teknologi komunikasi yang ada sebagai peluang bisnis untuk meningkatkan perekonomian keluarga. Pemuda - pemudi setempat dalam karangtaruna khususnya tentunya juga ikut andil dalam pelatihan ini guna menambah pengetahuan mereka dan menjadikan mereka enterpreneur yang bergerak dalam jual beli secara online.

Beberapa hasil pengabdian sebelumnya adalah : pelatihan pemanfaatan internet merupakan kegiatan untuk memperoleh tambahan keteram pilan dan pengetahuan serta aplikasi dalam rangka meningkatkan efisiensi dan efektivitas pengelolaan organi sasi, Hasil pengamatan selama proses kegiatan dapat dilihat bahwa rata-rata penerimaan materi yang disampaikan oleh instruktur cukup baik. Untuk lebih meningkatkan ketram pilan yang telah diperoleh maka perlu kiranya para peserta untuk lebih banyak berlatih dan mulai menerapkan dalam proses administrasi di organisasinya(Maskan, Soepeno, Adisaksana, \& Rohani, 2018), Gambaran umum teknologi yang akan diterapkan, 1. Dalam bentuk kuliah: Peserta dikumpulkan di ruangan tertentu diberi kuliah tentang materi layanan dalam bentuk manajemen pemasaran, terutama bauran promosi., 2. Bimbingan dan Pelatihan: Dalam bentuk pelatihan dan pengorganisasian pelatihan khusus campuran promosi dan diskusi tentang pengalaman dan kendala di lapangan.3. Praktik simulasi: Ini adalah demonstrasi bagaimana pengusaha mempromosikan barang dan dengan alat apa barang tersebut dipromosikan.4. Berlatih memajang barang di rak / gantungan (Samboro, Hasan, Helmy, \& Pribadi, 2018), Diharapkan dengan adanya media pendukung pembelajaran ini dapat meningkatkan ketersediaan sarana belajar mengajar di lingkungan TPQ dan dapat meningkatkan motivasi belajar santri serta dapat digunakan oleh orang awam yang berkehendak belajar Al-Qur'an tetapi terkendala masalah waktu dan lain-lain. Perangkat Lunak yang akan dikembangkan menggunakan teknologi berbasis website agar dapat digunakan di mana saja dan kapan saja menggunakan koneksi internet (Learning, Tilawati, Of, \& Branch, 2019), Hasil kegiatan menunjukkan adanya peningkatan pengetahuan dan pemahaman peserta terhadap pentingnnya komunikasi efektif dalam bentuk pengemasan pesan beserta teknik publikasinya bagi pelaku UMKM dan kelompok sadar wisata di desa Bongas. Kesimpulan kegiatan pengabdian kepada masyarakat ini adalah bahwa potensi keragaman pariwisata akan semakin terkelola dengan baik apabila dilakukan dengan penyampaian pesan secara

Teknologi Informasi dan Komunikasi 
efektif mengenai objek wisata ke masyarakatmelalui skema pemberdayaan masyarakat yang partisipatif (Nugraha et al., 2019), Permasalahan mitra diatasi melalui penerapan manajemen dan teknik pemasaran produk mitra dengan menggunakan media internet (online). Berdasarkan hasil kegiatan diperoleh: 1) terdapat peningkatan pemahaman pentingnya teknologi terhadap usaha; 2) meningkatnya kemampuan dalam pengelolaan teknologi internet; 3) peningkatan dalam penyerapan pasar; 4) Peningkatan kemampuan komunikasi bagi mitra dalam mengelola website dan Social Media Marketing, yaitu kemampuan mitra mengkomunikasikan produk dan merk produk sehingga memiliki daftar pelanggan tetap pada website yang berpotensi melakukan pembelian produk secara berkelanjutan (Harto, Pratiwi, Utomo, \& Rahmawati, 2019), Metode yang digunakan adalah pelatihan yang disertai dengan ceramah, demonstrasi, praktek dan evaluasi. Ada 2 jenis evaluasi yang dilakukan yaitu pre test dan post test. Pre test dilaksanakan sebelum kegiatan pelatihan dimulai. Post test dilakukan setelah semua kegiatan pelatihan selesai dilaksanakan. Hasil dari pelatihan menunjukan nilai sig. (2-Tailed) pre test ke post test sebesar 0,016 dengan taraf signifikansi 0,001 $(\mathrm{p}<0,05)$. Hal ini menunukan bahwa ada pengaruh yang signifikan pelatihan terhadap peningkatan keterampilan peserta dalam bidang reparasi dan perawatan alat listrik rumah tangga seperti Setrika Listrik, Rice Cooker, Blender, Mixer dan Kipas Angin (Sardi \& Pulungan, 2019), Pelatihan berlangsung selama 1 (satu) hari diikuti oleh para pengelola pariwisata setempat seperti unsur Dinas Pariwisata Kabupaten Garut, anggota Kelompok Sadar wisata (POKDARWIS) setempat, siswa setingkat SMA, dan anggota masyarakat lainnya. Animo peserta pelatihan cukup tinggi dan mereka merasakan manfaat pelatihan untuk diterapkan dalam bermedia sosial. Pelatihan lanjutan masih dibutuhkan, khususnya terkait keterampilan mengenai pengemasan pesan dalam bentuk multimedia (Lokal, Pantai, Heualang, \& Garut, 2017).

\section{METODE}

Metode pendekatan yang dilakukan oleh tim pengabdian masyarakat Teknik Informatika Unika
Musi Charitas pada program ini dapat dirinci menjadi 4 tahap yaitu:

- Tahap 1: Koordinasi dengan pihak dari kelompok masyarakat di daerah Mariana, Banyuasin.

- Tahap 2: Pelatihan pengenalan dan pembutan toko online bagi kelompok masyarakat di daerah Mariana, Banyuasin.

- Tahap 3: Pelatihan kewirausahaan yang meliputi pengenalan potensi diri, pengenalan potensi usaha, kreativitas dan inovasi dalam menjalankan usaha, modal untuk berwirausaha serta tips untuk berwirausaha.

- Tahap 4: Melakukan uji coba implementasi registrasi dan implementasi toko on-line

Secara ringkas, metode pelaksanaan program yang dilakukan untuk menyelesaikan persoalan mitra dalam gambar 1 berikut:

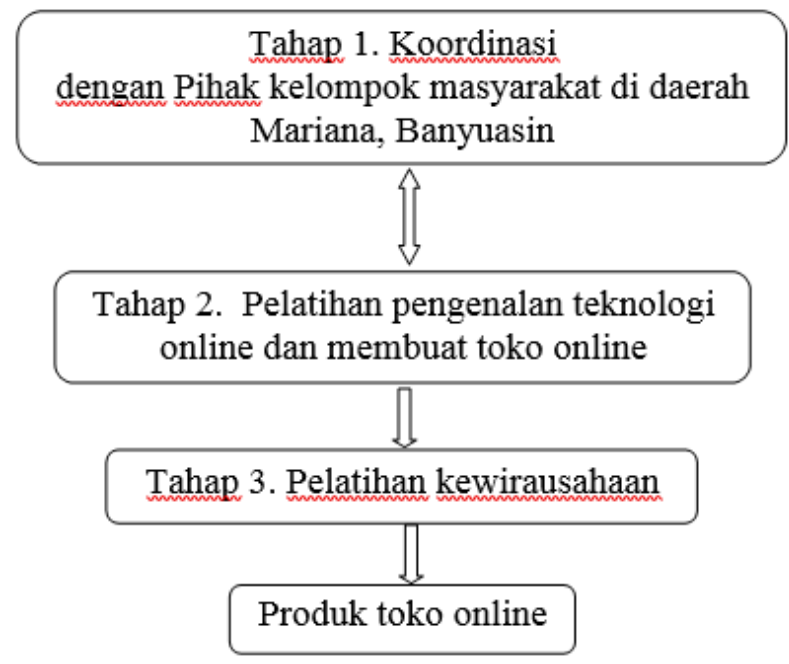

Gambar 1. Metode Pelaksanaan Program Pengmas Prodi Teknik Informatika UKMC

\section{HASIL DAN PEMBAHASAN}

\section{Hasil Pengabdian Implementasi Toko On-Line}

Kegiatan pengabdian kepada masyarakat yang telah dilakukan saat ini hanya sebatas implementasi pembuatan toko online dengan basis mobile. Toko online yang dibuat mengambil layanan dari penyelenggara e-commerce yang berada di Indonesia. Shopee penyedia aplikasi untuk penjualan online dengan fitur - fitur yang diterapkan pada pertemuan pengabdian kepada masyarakat, fitur yang telah diterapkan adalah :

Teknologi Informasi dan Komunikasi 
a. Registrasi : pendaftaran dengan email yang telah dibuat sebelumnya

b. Update profil : perubahan dari data penjual

c. Upload barang yang dijual secara online

d. Menjual barang toko online lainnya (reseller)

e. Melihat chat respon dari pembeli *

f. Melihat permintaan / respon dari pembeli yang meng-order barang *

(* dilakukan uji coba dan tidak semua peserta melakukannya, uji coba dilakukan setelah 1 hari acara selesai)

Hasil secara keseluruhan peserta untuk pembuatan toko online menggunakan aplikasi shopee telah dapat dibuat dimasing - masing perangkat mobile peserta.

\section{Pembahasan Implementasi Toko On-Line}

Respon dari peserta dalam kegiatan ini dapat dilihat dari kuisioner yang telah diisi, tentunya untuk melihat dampak dari kegiatan ini membutuhkan waktu minimal 1 semester atau 6 bulan dengan pendampingan yang aktif setiap bulannya.

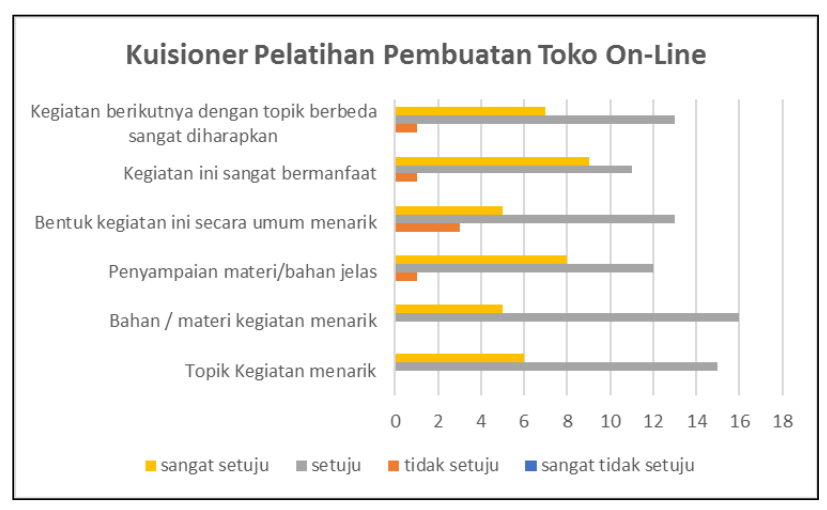

Gambar 2. Grafik rekap kuisioner toko online

Gambar 2 dapat menjelaskan bahwa kegiatan ini dapat membawa dalam hal positif dari sisi tambahan ilmu pengetahuan teknologi guna memperbanyak kegunaan dan fungsi dari perangkat mobile yang dimiliki masyarakat. Pembuatan toko online yang tadinya belum banyak diketahui oleh masyarakat, dengan adanya infrastruktur (jaringan telekomunikasi/internet) dan perangkat yang dimiliki oleh masyarakat (smart phone) ditambah dengan tim yang menyelenggarakan kegiatan pembuaatan toko online tentunya masyarakat sudah dapat mengetahui toko online, terutama pada penyelenggara layanan toko online seperti shopee.

\section{KESIMPULAN}

Sosialisasi dan pelatihan yang diterapkan pada mitra hanya sebatas implementasi, untuk itu kesimpulan dari hasil penerapan ini adalah :

a. infrastruktur dan perangkat yang dimiliki oleh mitra dapat digunakan untuk membuat layanan penjualan secara online yang menggunakan web e-commerce gratis

b. produk sendiri dan yang didapatkan dari pihak lain dapat dijadikan materi untuk mengisi konten penjualan pada aplikasi

\section{REFERENSI}

Jongko. (2009) Sabun Kecantikan: Teori dan Praktek Membuat Sabun Beauty di Rumah. Jakarta.

VH. S.E. dan Susilowati E. (2016) Pemberdayaan Ibu-Ibu PKK Melalui Pelatihan dan Pendampingan Produksi sabun dan Deterjen. Jurnal semar Vo. IV No. 2 November 2016.Hal, 87-95.

Harto, D., Pratiwi, S. R., Utomo, M. N., \& Rahmawati, M. (2019). Penerapan Internet Marketing Dalam Meningkatkan Pendapatan Pada Umkm. Jurnal Pengabdian Dan Pemberdayaan Masyarakat, 3(1), 39-45.

Learning, A. A. N., Tilawati, U., Of, M., \& Branch, M. (2019). Penerapan Perangkat Lunak Multimedia Interaktif Pembelajaran Al- Qur' An Dengan Metode Tilawati Cabang. JPPM (Jurnal Pengabdian Dan Pemberdayaan Masyarakat), 3(1), 173-178. https://doi.org/10.30595/jppm.v3i1.3645

Lokal, K., Pantai, D. I., Heualang, S., \& Garut, K. A. B. (2017). Pelatihan Pemanfaatan Media Sosial Untuk Promosi Pariwisata Dan Potensi Kearifan Lokal Di Pantai Sayang Heualang Kab. Garut. Jurnal Pengabdian Kepada Masyarakat, 2, No 12.

Maskan, M., Soepeno, B., Adisaksana, H., \& Rohani, S. (2018). Pelatihan Pemanfaatan Internet Untuk Menunjang Pelaksanaan Tugas 
Administrasi Pada Aparatur Desa Tegalweru Kecamatan Dau Kabupaten Malang. JABDIMAS, 5(1), 71-78.

Nugraha, A. R., Perbawasari, S., Zubair, F., Novianti, E., Nugraha, A. R., Perbawasari, S., ... Novianti, E. (2019). Pemberdayaan Masyarakat Melalui Pelatihan Komunikasi Efektif Berbasis Potensi Wisata Dan Kearifan Lokal. JPPM (Jurnal Pengabdian Dan Pemberdayaan Masyarakat), 3(1), 123-132. https://doi.org/10.30595/jppm.v3i1.3546

Samboro, J., Hasan, H., Helmy, A., \& Pribadi, J. D. (2018). Bimbingan Dan Pelatihan Tentang Pentingnya Bauran Promosi Bagi Pengembangan Usaha Di Clothing \& Jacket Jonggring Malang. J-ABDIMAS, 5 no.1, 66-71.

Sardi, J., \& Pulungan, A. B. (2019). Pelatihan Reparasi dan Perawatan Alat Listrik Rumah Tangga untuk Pemuda Pesisir. JPPM (Jurnal Pengabdian Dan Pemberdayaan Masyarakat), 3(1), 1-4. Retrieved from http://jurnalnasional.ump.ac.id/index.php/JPP M/article/view/2396/2428 